\title{
Overexploitation of Rays and Sharks in the Mediterranean Sea
}

\section{Monique Mancuso}

Institute for Coastal Marine Environment (IAMC) - National Research Council (CNR) -Section of Messina, Italy

*Corresponding author: Monique Mancuso, Institute for Coastal Marine Environment (IAMC) - National Research Council (CNR) -Section of Messina, Spianata S. Raineri, Messina, Italy, Tel: (+39) 0815423804; E-mail: monique.mancuso@iamc.cnr.it

Received date: February 20, 2015; Accepted date: February 23, 2015; Published date: March 03, 2015

Copyright: () 2015 Mancuso M. This is an open-access article distributed under the terms of the Creative Commons Attribution License, which permits unrestricted use, distribution, and reproduction in any medium, provided the original author and source are credited.

\begin{abstract}
Mediterranean basin is one of the first 25 Global Biodiversity Hotspots; there are several species of Elasmobranchs (49 sharks and 36 rays). Unfortunately, the overexploitation of these fish in Mediterranean together with a lack of the biology and their biological characteristic (low growth rate, late sexual maturity and low fecundity, low rates of biomass turnover) has meant that many species are now threatened with extinction. Today many sharks and rays are listed on the Red List of threatened species by the International Union for the Conservation of Nature (IUCN) and several European convention are trying to ensure the conservation of endangered and vulnerable species. Further multifocal studies are necessaries to define the criteria for protection and prevention on endangered Mediterranean species.
\end{abstract}

Keywords: Elasmobranchs; Overfishing; Mediterranean Sea

\section{Introduction}

The Mediterranean Sea is a semi-enclosed marine basin characterized by complex and diverse marine communities $[1,2]$.

Mediterranean basin is one of the world's richest places in terms of animal and plant diversity [3] and it was recognized as one of the first 25 Global Biodiversity Hotspots [4].

In the Mediterranean sea Elasmobranchs are characterized by their diversity with 49 sharks and 36 rays [5-8].

Unfortunately, the exploitation of the Mediterranean Sea [9] along with the biological characteristics of the Elasmobranchs (i.e. low growth rate, late sexual maturity and low fecundity, low rates of biomass turnover) [10], has meant that many species are over exploited and extinction threatened [11]. In the last 200 years there was a dramatic decline of large predatory sharks in the Mediterranean Sea. In addition, there is a lack of knowledge on the biology and fishery of Elasmobranchs in many parts of the Mediterranean, for many species there is a total absence of data [12].

Today, many sharks and rays are listed on the Red List of threatened species by the International Union for the Conservation of Nature (IUCN).

The Convention on the Conservation of European Wildlife and Natural Habitats (1982) as well as Convention for the Protection of the Mediterranean Sea against Pollution, Protocol on Specially Protected Areas and Biological Diversity (1995), Action Plan for the Conservation of Cartilaginous Fishes in the Mediterranean Sea and the EU Action Plan for the Conservation and Management of Sharks ensure the conservation of wild flora and fauna species and their habitats giving special attention to endangered and vulnerable species.

All these protection measures together with a multifocal study comprising: monitoring of the species and their environment, a detailed study of the biology of the species and their ecological role and the analysis of the Elasmobranchs community must be made by further research to define the criteria for protection and prevention on endangered Mediterranean species.

\section{References}

1. Tortonese E (1964) The main biogeographical features and problems of the Mediterranean fish fauna. Copeia 1: 98-107.

2. Garibaldi L, Caddy JF (1998) Biogeographic characterization of Mediterranean and Black Seas faunal provinces using GIS procedures. Oce Coa Man 39: 211-227.

3. Cuttelod A, García N, Malak AD, Temple H, Katariya V (2008) The Mediterranean: a biodiversity hotspot under threat. In: Vié JC, HiltonTaylor C, Stuart SN (eds). The 2008 Review of The IUCN Red List of Threatened Species. IUCN Gland, Switzerland.

4. Myers N, Mittermeier RA, Mittermeier CG, da Fonseca GAB,Kent J (2000) Biodiversity hotspots for conservation priorities. Nature 403: 853-858.

5. Serena F, Mancusi C, Barone M (2005) Abundance and distribution of rays in the south ligurian and north tyrrhenian sea. Theme session on elasmobranch fisheries science (N). ICES Document CM pp: 20.

6. Rinelli P, Bottari T, Florio G, Romeo T, Giordano D, et al. (2005) Observations on distribution and biology of Galeus melastomus (Chondrichthyes, Scyliorhinidae) in the Southern Tyrrhenian Sea (Central Mediterranean). Cybium 29: 41-46.

7. Bottari T, Rinelli P, Bianchini ML, Ragonese S (2013) Stock identification of the thornback ray (Raja clavata L.) In two contiguous areas of the Central Mediterranean Sea. Hydrobiologia 703: 215-224.

8. Bottari T, Busalacchi B, Profeta A, Mancuso M, Giordano D, et al. (2014) Elasmobranch Distribution and Assemblages in the Southern Tyrrhenian Sea (Central Mediterranean). J Aquac Res Development 5: 216.

9. Lotze HK, Lenihan HS, Bourque BJ, Bradbury RH, Cooke RG, et al. (2006) Depletion, Degradation, and recovery potential of estuaries and coastal seas. Science 312: 1806-1809.

10. Hoening JM, Gruber SH (1990) Life-history patterns in the elasmobranchs: Implications for fisheries management. Pratt HLJ, Gruber SH, Tianiuchi T (eds). Elasmobranchs as living resources: advances in the biology, ecology, Systematics, and the status of fisheries, Washington.

11. Ferretti F, Myers R, Serena F, Lotze H (2008) Loss of large predatory sharks from the Mediterranean Sea. Conserv Biol 22: 952-964. 
Citation: Mancuso M (2015) Overexploitation of Rays and Sharks in the Mediterranean Sea. J Biodivers Endanger Species 3: e123. doi: $10.4172 / 2332-2543.1000 \mathrm{e} 123$

Page 2 of 2

12. Field IC, Meekan MG, Buckworth RC, Bradshaw CJA (2009) Susceptibility of sharks, rays and chimaeras to global extinction. Advances in Marine Biology 56: 275-363. 